\title{
Ekonomi-skam modellen och reaktioner på arbetslöshet
}

\author{
LEIF R. JÖNSSON \& BENGT STARRIN
}

\begin{abstract}
Det är känt att människor reagerar olika på arbetslösheten, men det är mindre känt vad det är som gör att en del förblir opåverkade av arbetslösheten, medan den blir till en plåga för andra. I artikeln analyseras och diskuteras - i ljuset av ekonomi-skam modellen-olika reaktioner på arbetslöshet uttryckt som fyra olika typbeskrivningarOpåverkade, Besvärade, Omskakade, Plågade.
\end{abstract}

Den moderna forskningen om vad arbetslöshet kan innebära för den enskilde har i huvudsak varit inriktad på att studera på förhand väl avgränsade aspekter genom operationellt definierade variabeluppsättningar. Detta skiljer den moderna forskningen från den arbetslöshetsforskning som bedrevs under 30-talets depressionsår och som emellanåt går under beteckningen den "gamla" arbetslöshetsforskningen. Väl medveten om att arbetslöshetens individuella

Leif R. Jönsson är fil.lic. i socialt arbete. Han är verksam som omvärldsanalytiker, med inriktning på socialpolitik, vid Utvecklingsnämnden, Helsingborgs stad och doktorand vid Socialhögskolan $\mathrm{i}$ Lund.

Bengt Starrin är professor i socialt arbete vid Karlstads universitet, Institutionen för samhällsvetenskap.

Detta arbete har utförts med finansiellt stöd från Socialvetenskapliga forskningsrådet. konsekvenser är komplexa och sammansatta arbetade man inom den "gamla" forskningen i stor utsträckning med att skapa idealtyper - ibland benämnda typologier.

Föregångarna på området var Marie Jahoda, Paul F. Lazarfeld och Hans Zeisel, som i sin berömda undersökning av arbetslösheten i Marienthal urskiljde fyra kategorier arbetslösa, som de benämnde de sobrutnaı, de sresigneradeı, de sförtvivlade och de rapatiskar (Jahoda, Lazarsfeld, Zeisel 1974. Original på tyska -1933). Till grund för klassificeringen använde forskargruppen information om bl.a. hushållens skötsel, hushållens tidsanvändning, hushållens penningbudget, det vardagliga livet. De använde sig av olika metoder som t.ex. intervjuer, observationer och dokument.

Marientalforskarna kunde påvisa ett tydligt samband mellan ekonomiska förhållan-

Jönsson, L.R. \& Starrin, B. : Ekonomi-skam modellen... 
den och reaktioner på arbetslöshet. Sambanden var så tydliga att de kunde tillåta sig att fastslå att det var möjligt att på ett ungefär kunna förutsäga vad som krävdes i inkomstförsämring för att en familj skulle knuffas ner till nästa lägre kategori (Jahoda, Lazarsfeld och Zeisel 1974, sid 81).

År 1934 publicerade Beales och Lambert en studie där de analyserade 25 berättelser nedtecknade av arbetslösa (Beales \& Lambert, 1934). De delade in de arbetslösa i tre olika kategorier - ^Optimistiskaı, ıPessimistiska och 'Fatalistiska - beroende på den sinnesstämning som framträdde i berättelserna.

Året därpå publicerade Zawadski och Lazarsfeld analyser av 57 självbiografier skrivna av arbetslösa. Författarna klassificerade de arbetslösa i fyra olika grupper - ıbrutnaı, 'Resigneradeı, 'Apatiskar och `Nödställdar. Det som karaktäriserade de nödställda var att de inte bara var utsatta för fysiskt lidande orsakat av ekonomisk deprivation, utan att de också var utsatta för lidande som orsakats av förändrad social status. På grund av att de hade varit med om upprepade nedklassningar hade de förlorat känslan av värdighet, vilket resulterat i ett intensivt lidande. De flesta skämdes också över sin misär (Zawadski \& Lazarsfeld 1935, sid. 238).

År 1938 publicerade Eisenberg och Lazarsfeld en studie där de sammanfattade den dittillsvarande arbetslöshetsforskningen genom att bl.a. beskriva olika psykologiska faser som arbetslösa går igenom. Den första fasen upplevs som en chock som följs av ett aktivt sökande efter jobb. Under den första fasen är den arbetslöse soptimistiskı och obruten av arbetslösheten. Den andra fasen inträder när alla försök att få jobb misslyckas. Den arbetslöseblir nu 'pessimistiskı och ängslig. Under den tredje fasen blir den abetslöse ıfatalistiskı och är nu nedbruten av arbetslösheten (Eisenberg \& Lasarsfeld, 1938).

Det finns åtskilliga likheter i de olika klassificeringarna av reaktioner på arbetslöshet som kännetecknade pionjärernas forskning. Begrepp som ıObrutnaı, ,Resignerader och ıApatiskar återkommer i flera typologier. Typologierna, även om de kritiserats för att vara osystematiskt tillkomna, bestod av sammansatta och informationstäta beskrivningar. Ofta kombinerades kvantitativa data med kvalitativa data som möjliggjorde inlevelse (Jahoda, Lazarsfeld och Zeisel, 1974). Även om det inom den moderna arbetslöshetsforskningen inte hört till vanligheten med ansatser som syftat till att formulera sammansatta typbeskrivningar av reaktioner på arbetslöshet finns en del studier redovisade. Vi skall kortfattat ta upp några nutida svenska exempel. I en kvalitativ studie identifierade Starrin och Larsson (1987) fyra reaktioner på arbetslöshet bland kvinnor. De fyra grupper som identifierades var `Uppgivarna`, 'Fasthållarnaı, ’Omcentrerarnar och sAmbivalenternar.

I sin studie av nedläggningen av Öresundsvarvet i Landskrona fann Angelöw (1985) fyra typer av reaktionsmönster hos de uppsagda. En femtedel eller ca 20 procent var ,Oberördaı. En lika stor andel ıNågot berördaı. Hälften var `Olustfyllda och oroligaı och 10 procent `Förtvivladeı.

Berg (1997) urskiljde i sin studie fyra olika kategorier bland de arbetslösa. ıFörnyarenı sökte vägar att ta sig tillbaka till arbetslivet. ı Återställaren ‘ önskade finna en 
väg tillbaka till sina tidigare roller i arbetslivet vilket kunde leda till upplevelser av frustration. PPassageraren hade funnit alternativ till arbete. Därför fanns det inte heller någon anledning till att anstränga sig. IDen frustrerader kände sig sviken och hade få förväntningar på framtiden. ıDen frustrerader riskerade att bli apatisk.

Till grund för föreliggande undersökning har ett försök gjorts att, mot bakgrund av tidigare forskning, formulera fyra sammansatta typer av reaktioner på arbetslöshet som sammanfattas med orden "Opåverkade», »Besvärade», "Omskakade» och »Plågade» av arbetslösheten.

\section{Undersökningens syfte}

Syftet med föreliggande undersökning är att studera sambandet mellan ekonomiska och sociala förhållanden - uttryckt i ekonomiskam modellen - och reaktioner på arbetslöshet uttryckt som beskrivningar av fyra olika typer av reaktioner på arbetslöshet.

\section{Ekonomi-skam modellen}

I denna studie kommer ekonomi-skam modellen att utgöra en ram för vår analys. Modellen har utvecklats i syfte att öka förståelsen för varför en del individer knappast alls påverkas negativt av arbetslösheten medan den för andra leder till allvarliga hälsobesvär och deprivation (Starrin, Rantakeisu \& Hagquist, 1996; Starrin, Rantakeisu \& Hagquist, 1997; Starrin, Jönsson, Forsberg \& Rantakeisu, 1998; Starrin \& Jönsson, 1998; Rantakeisu,Starrin \& Hagquist, 1999; Starrin, Forsberg \& Rantakeisu, 1999).

Ekonomi-skam modellen sammanlänkar två forskningstraditioner. Den ekonomiska aspekten i modellen knyter an till forskning kring ekonomisk stress och deprivation (Horowitz,1984), medan den sociala aspekten knyter an till den mikrosociologiska forskningen om sociala band (Scheff, 1990), sociala nätverk (Berkman \& Syme, 1979), självbild och identitet (Hayes \& Nutman, 1981). Ekonomi-skam modellen fäster avseende vid det som i varierande grad kan tänkas gå förlorat vid arbetslöshet nämligen å ena sidan inkomster i form av lön och å andra sidan social prestige, status och aktning.

Modellens ekonomiska aspekt uppmärksammar lönens betydelse. Den innefattar det värde som pengar har för att bygga upp, stabilisera och vidmakthålla en levnadsstandard. Forskningen som fokuserat på arbetslöshetens ekonomiska sida visar att ju svårare den ekonomiska situationen är under arbetslösheten desto större är risken att drabbas av ohälsa i någon form (se t.ex. Starrin, Rantakeisu \& Hagquist,1996; Viinamäki, Koskela K, Niskanen \& Arnkill, 1993, Mohr \& Frese, 1978; Starrin \& Lundberg, 1993; Hagquist, \& Starrin, 1996; Starrin \& Jönsson 1998; Giorgio \& Unge, 1998). När vi fortsättningsvis diskuterar arbetslöshetens ekonomiska sida kommer vi att använda begreppet ekonomisk påfrestning för att referera till de problem som kan uppstå i samband med att ekonomin inte går eller inte kommer att gå ihop och som yttrar sig $\mathrm{i}$ att man tvingas till extraordinära saker som t.ex. att pantsätta ägodelar, sälja ägodelar, låna pengar eller också att man inte förmått betala räkningar i tid.

Den andra aspekten som beaktas i ekonomi-skam modellenär det potentielltskam-

Jönsson, L.R. \& Starrin, B. : Ekonomi-skam modellen... 
fyllda i att vara arbetslös. Förutom att lönearbete ger en inkomst har det en social funktion. Det ger i varierande grad status, prestige och aktning. Föreställningar om att arbetslöshet beror på personliga egenskaper och attityder till arbete hos de arbetslösa själva har varit utbredda (Gallie, 1994).

Hur andra människor betraktar arbetslösa är betydelsefullt för den arbetslöses identitet (se t.ex. Jahoda,1982). Studier visar att många arbetslösa upptas av känslor om hur man bedöms och värderas av andra (Hayes \& Nutman, 1981). Den arbetslöses självbild sätts på prov i samband med möten med andra människor, auktoriteter och välfärdsinstitutioner.Känslornakan ibland vara starka och handla om ilska, vrede, skam och nedstämdhet (Wadel, 1973).

Begreppet skam kan både referera till en intensiv känsla och till en relation mellan två eller flera individer. Skam kan sägas vara mindervärdighetens eller underlägsenhetens känsla. Den är en känsla som väcks när individen plötsligt blir medveten om en tillviten svaghet hos det egna jaget, ett mål som inte nåtts eller en förväntan man inte kan leva upp till. Skam och dess besläktade känslor förödmjukelse och förnedring refererar till en smärta förorsakad av att det egna jaget, den egna stoltheten eller självbilden påverkas negativt. Ingen annan känsla förefaller heller vara så central för utvecklingen av identitet och självbild som just skamkänslan av det skälet att den är så plågsam (Kaufmann, 1993).

Skam som ett uttryck för kvaliteten i de sociala relationerna utgår från antagandet att när banden mellan människor hotas väcker det känslor (Scheff, 1990). Tillstånden i de sociala banden avläses oupphörligt och inte enbart genom att tolka det som sägs utan främst genom hur det sägs, dvs. genom människors uppträdande. Känslor av skam och dess motsats stolthet är signaler på de sociala bandens kvalitet - om de är ansträngda eller trygga. Skam och stolthet är emellertid känslor som har en tendens att trängas bort i det moderna, allt mer individualiserade samhället. Följden blir att individen skäms för att hon skäms. För Scheff är skam och stolthet känslor av social natur. Vad vi som människor känner skam respektive stolthet inför är kulturellt betingat (Scheff, 1990).

Eales visar i sin studie att känslor av skam är vanligt förekommande bland vuxna arbetslösa män (Eales, 1989). I Eales studie var skam också förbundet med psykiska problem som t.ex. nedstämdhet och oro. Studier har också visat att ju mer den arbetslöse erfar omgivningens ringaktning eller skamgörande på grund av arbetslösheten, i desto högre grad besväras den arbetslöse av ohälsa (Rantakeisu,Starrin \& Hagquist, 1997; Starrin \& Jönsson, 1998).

I undersökningen lyfter vi fram skamkänslans relationella sida genom att undersöka om man blivit betraktad på ett nedvärderande sätt under den tid man varit arbetslös. Det sammanfattande begreppet för detta är skamgörande erfarenheter.

Ekonomi-skam modellen refererar således till två förhållanden för att förstå reaktionerna på arbetslöshet, nämligen grad av ekonomisk påfrestning och grad av skamgörande erfarenheter. Hypotesen är att ju högre grad av ekonomisk påfrestning och ju mer skamgörande erfarenheter desto större andel som upplever sig vara plågad av arbetslösheten och ju lägre grad av ekonomisk 
Figur I

Ekonomi-skam modellen och reaktioner på arbetslöshet.

Skamgörande erfarenheter

\begin{tabular}{|lll|l|}
\multicolumn{1}{c}{} & \multicolumn{1}{c}{ Mer } & \multicolumn{1}{c}{ Mindre } \\
\cline { 3 - 4 } Ekonomisk & $\begin{array}{l}\text { Högre } \\
\text { grad }\end{array}$ & $\begin{array}{l}\text { Plågade av } \\
\text { arbetslösheten }\end{array}$ \\
\cline { 2 - 3 } påfrestning & $\begin{array}{l}\text { Lägre } \\
\text { grad }\end{array}$ & & $\begin{array}{l}\text { Opåverkade av } \\
\text { arbetslöshet. }\end{array}$ \\
& & &
\end{tabular}

påfrestning och ju mindre av skamgörande erfarenheter desto större andel som upplever sig vara opåverkade av den. Modellen åskådliggörs i figur 1.

\section{Metod}

Undersökningen är en s.k. tvärsnittsstudie. Den bygger på empiriskt data från en survey som genomfördes i Skåne hösten 1996. Undersökningen riktades mot arbetslösa som var placerade i arbetsmarknadspolitiska åtgärder i 14 av regionens 33 kommuner. De 14 kommunerna valdes ut mot bakgrund av två kriterier. För det första skulle det ingå stora, medelstora och små kommuner spridda över hela regionen och för det andra skulle det finnas pågående ALU-projekt i de utvalda kommunerna.

\section{Datainsamling}

Datainsamlingen ägde rum i samverkan med LO-distriktet i Skåne och vände sig till 1615 personer som under två mätveckor i september/oktober 1996 deltog i någon arbetsmarknadspolitisk åtgärd. 1249 per- soner besvarade formuläret. ${ }^{1}$ Detta betyder en svarsfrekvens på 77 procent. I hela regionen var vid undersökningstillfället totalt 6980 personer i ALU-åtgärd av något slag (3 701 män och 3279 kvinnor). Undersökningspopulationen utgjorde 18 procent av samtliga ALU-sysselsatta i regionen vid undersökningstillfället.

Frågeformulär delades ut direkt till deltagarna för att fyllas i anonymt. Det gick till på två olika sätt. På några orter delades formuläret ut till deltagarna som tog det med sig hem för att i lugn och ro fylla i formuläret och sedan återlämna det till den ansvarige projektledaren inom några dagar. Det vanligaste var dock att formuläret delades ut vid ett särskilt tillfälle. Formuläret fylldes i och återlämnades till projektledaren vid samma tillfälle.
1 På grund av s.k. internt bortfall är n-talet i de redovisade tabellerna genomgående mindre än 1249.

Jönsson, L.R. \& Starrin, B. : Ekonomi-skam modellen... 


\section{Undersökningsinstrument}

Frågeformuläret innehåller frågor om sociala bakgrundsförhållanden som t.ex. kön, ålder, utbildning, familjeförhållanden, etnisk bakgrund och hur länge man varit arbetslös. Vidare ingår ett antal frågor om ekonomiska förhållanden t.ex. om man p.g.a. arbetslösheten tvingats pantsätta ägodelar, låna pengar, sälja ägodelar och om man har en s.k. ekonomisk buffert (kontantmarginal). Andra frågor i formuläret handlar om skamgörande erfarenheter t.ex. om man blivit ignorerad, betraktad som lat, betraktats som okunnig, varit med om att andra talat nedsättande om arbetslösa. Dessutom innehåller det frågor om olika aspekter på hälsa.

Sammanvägda mått på ekonomisk påfrestning och skamgörande erfarenheter

De sammanvägda måtten för faktorerna "ekonomisk påfrestning" och "skamgörande erfarenheter" som konstruerats för ekonomi-skam modellen har bildats med hjälp av faktoranalys enligt metoden "Principal Components, Rotation Varimax«. Faktorpoäng har bildats med metoden "Regression". De båda faktorerna har indelats i tre lika stora grupper så att en tredjedel faller inom det som benämns "högre grad av ekonomisk påfrestning", en tredjedel inom "medelgrad av ekonomisk påfrestning» och en tredjedel inom "lägre grad av ekonomisk påfrestning". Mätfaktorn "skamgörande erfarenheter» indelades på samma sätt, dvs. mer, medel respektive mindre.

I figur 2 redovisas de frågor som ingår i de sammanvägda måtten på ekonomisk påfrestning och skamgörande erfarenheter.
Mått på reaktioner på arbetslöshet - fyra typbeskrivningar

En fråga i formuläret var utformad som fyra påståenden om hur man kan uppleva situationen som arbetslös. Påståendena refererade till beskrivningar av fyra typer av reaktioner på arbetslöshet som kan sammanfattas med orden "Opåverkade», "Besvärade», "Omskakade» och „Plågade». Undersökningsdeltagarna ombads att ta ställning till dessa fyra beskrivningar och ange vilken av dessa som passade bäst in på dem själva. Dessa redovisas i figur 2.

\section{Dataanalys}

Data har bearbetats i SPSS bl.a. med hjälp av faktoranalys, konventionell tabellanalys och multipel logistisk regressionsanalys.

\section{Resultat}

\section{Beskrivning av undersökningsgruppen}

Av tabell 1 framgår att det finns något fler män än kvinnor i undersökningsgruppen. Åldersmässigt är gruppen i åldern 30-39 år störst. Drygt 60 procent har svensk bakgrund, ungefär en tredjedel är utlandsfödda och en mindre andel, 6 procent, är s.k. andra generationens invandrare. Medelarbetslöshetstiden är 30 månader $(s=23,1)$ och ca en tredjedel av respondenterna har lång arbetslöshetserfarenhet - 3 år eller längre. Populationens medelålder är 39,9 år $(s=11,6)$. Var fjärde är 50 år eller äldre och nästan var fjärde är under 30 år.

I tabell 2 redovisas reaktioner på arbets- 

Figur 2.
Operationalisering av Ekonomi-skam modellen samt reaktioner på arbetslöshet.

\section{EKONOMISK PÅFRESTNING}
- Har Du sedan Du blev arbetslös tvingats sälja ägodelar för att klara av Dina utgif- ter?
- Har du sedan du blev arbetslös tvingats att pantsätta ägodelar för att klara av Dina utgifter?
- Har Du sedan Du blev arbetslös tvingats låna pengar för att klara Dina utgifter?
- Har det sedan Du blev arbetslös hänt att Du inte har kunnat betala räkningar i tid, på grund av att Du inte haft pengar?
- Ja,flera gånger
- Ja, någon enstaka gång
- Nej
- Om Du plötsligt skulle hamna i en oför- utsedd situation, där Du på en vecka måste skaffa fram 14.000 kr, skulle Du då kunna klara detta?
- Ja, utan svårighet
- Ja,men med svårighet
- Nej

\section{SKAMGÖRANDE ERFARENHETER}
- Har Du känt att andra inte brytt sig om det Du sagt eller det Du gjort, därför att Du är arbetslös?
- Har Du känt att andra betraktat Dig som mindre kunnig därför att Du går utan arbete?
- Har Du känt att andra betraktat Dig som lat därför att Du går utan arbete?
- Har Du varit med om att människor varit irriterade på Dig därför att Du går utan arbete?
- Har Du upplevt att andra hållit sig undan Dig därför att Du går utan arbete?
- Har Du sedan Du blev arbetslös varit med om att andra talat nedsättande om de som är arbetslösa
- Ja, många gånger
- Ja, några gånger
- Ja, någon enstaka gång
- Nej, aldrig

\section{REAKTIONER PÅ AR ETS ÖSHET}

Den fråga som ställdes var:

- Här följer några vanliga beskrivningar av hur den som drabbats av arbetslöshet kan uppleva situationen. Sätt ett kryss i rutan för den beskrivning som just nu passar bäst in på Dig.

Opåverkade:»Arbetslösheten har inte påverkat mig alls. Jag känner mig tillfreds med min tillvaro just nu.Jag har hittills gått opåverkad ur situationen. Jag oroar mig inte för vad som kommer att hända i framtiden. Jag tror att saker och ting kommer att ordna sigu.

Besvärade: »Arbetslösheten har påverkat mig. Det har varit en besvärande tid. Jag är inte oberörd av situationen.Jag känner mig lite nedstämd och lite orolig för vad som kommer att hända i framtiden.«

Omskakade: »Att vara arbetslös har varit en omskakande upplevelse för mig. Jag känner mig ofta nedstämd - det går inte att förneka. Det känns olustigt och oroligt på något sätt.Jag är orolig för vad som skall hända i framtiden.«

Plågade: »Att vara arbetslös har varit plågsamt. Jag har känt mig mycket orolig, förtvivlad och nedstämd av att vara utan arbete. Tankar på vad som skall hända i framtiden gnager inom mig - tänk om jag inte lyckas få något nytt jobb. Jag känner mig mycket otillfredsställd med min tillvaro just nu.«

Jönsson, L.R. \& Starrin, B. : Ekonomi-skam modellen... 


\begin{tabular}{|c|c|c|}
\hline & Antal & Procent \\
\hline \multicolumn{3}{|l|}{ Kön } \\
\hline Kvinna & 608 & 49 \\
\hline Man & 623 & 51 \\
\hline \multicolumn{3}{|l|}{ Ålder } \\
\hline-29 år & 278 & 23 \\
\hline 30-39 år & 367 & 30 \\
\hline 40-49 år & 278 & 23 \\
\hline 50-64 år & 300 & 25 \\
\hline \multicolumn{3}{|l|}{ Familjetyp } \\
\hline Samboende utan barn & 299 & 25 \\
\hline Ensamstående utan barn & 390 & 32 \\
\hline Samboende med barn & 356 & 30 \\
\hline Ensamstående med barn & 163 & 14 \\
\hline \multicolumn{3}{|l|}{ Etnicitet } \\
\hline Svensk & 754 & 62 \\
\hline I:a gen. invandrare & 388 & 32 \\
\hline 2:a gen. invandrare & 71 & 6 \\
\hline \multicolumn{3}{|l|}{ Utbildning } \\
\hline Högst folkskola/grundskola/ realskola el. motsv. & 418 & 38 \\
\hline 2-årig gymn.skola /yrkesskola/ lärlingsutb /folkhögskola & a 391 & 34 \\
\hline 3-årig teoretiskt gymnasieskola/ högskola/ universitet & 341 & 29 \\
\hline \multicolumn{3}{|l|}{ Arbetslöshetstidens längd } \\
\hline 1-12 mån. & 332 & 27 \\
\hline 13-24 mån. & 312 & 25 \\
\hline 25-36 mån. & 207 & 17 \\
\hline 37 mån. - el. längre & 398 & 32 \\
\hline
\end{tabular}

löshet i relation till sociala bakgrundsförhållanden.

Av tabell 2 framgår att 18 procent av undersökningsgruppen upplever sig vara Opåverkade, 40 procent Besvärade, 18 procent Omskakade och 25 procent Plågade av arbetslösheten. Andelen kvinnor respektive män fördelar sig ungefär lika i förhållande till de fyra idealtyperna.

Den största andelen Opåverkade återfinns bland dem i åldersgruppen 50-64 år och bland dem som är sammanboende utan hemmavarande barn. Den största andelen som upplever sig vara Plågade av arbetslös- heten återfinns bland dem som har hemmavarande barn, bland dem som är i åldersgruppen 40-49 år och bland dem som är första generationens invandrare.

\section{Ekonomisk påfrestning, skamgörande erfarenheter och reaktioner på arbetslöshet}

I tabell 3 redovisas grad av ekonomisk påfrestning i relation till upplevelser av arbetslöshet bland kvinnor och män.

Av tabell 3 framgår att ju högre grad av ekonomisk påfrestning desto större andel som ärPlågade av arbetslösheten och ju lägre 


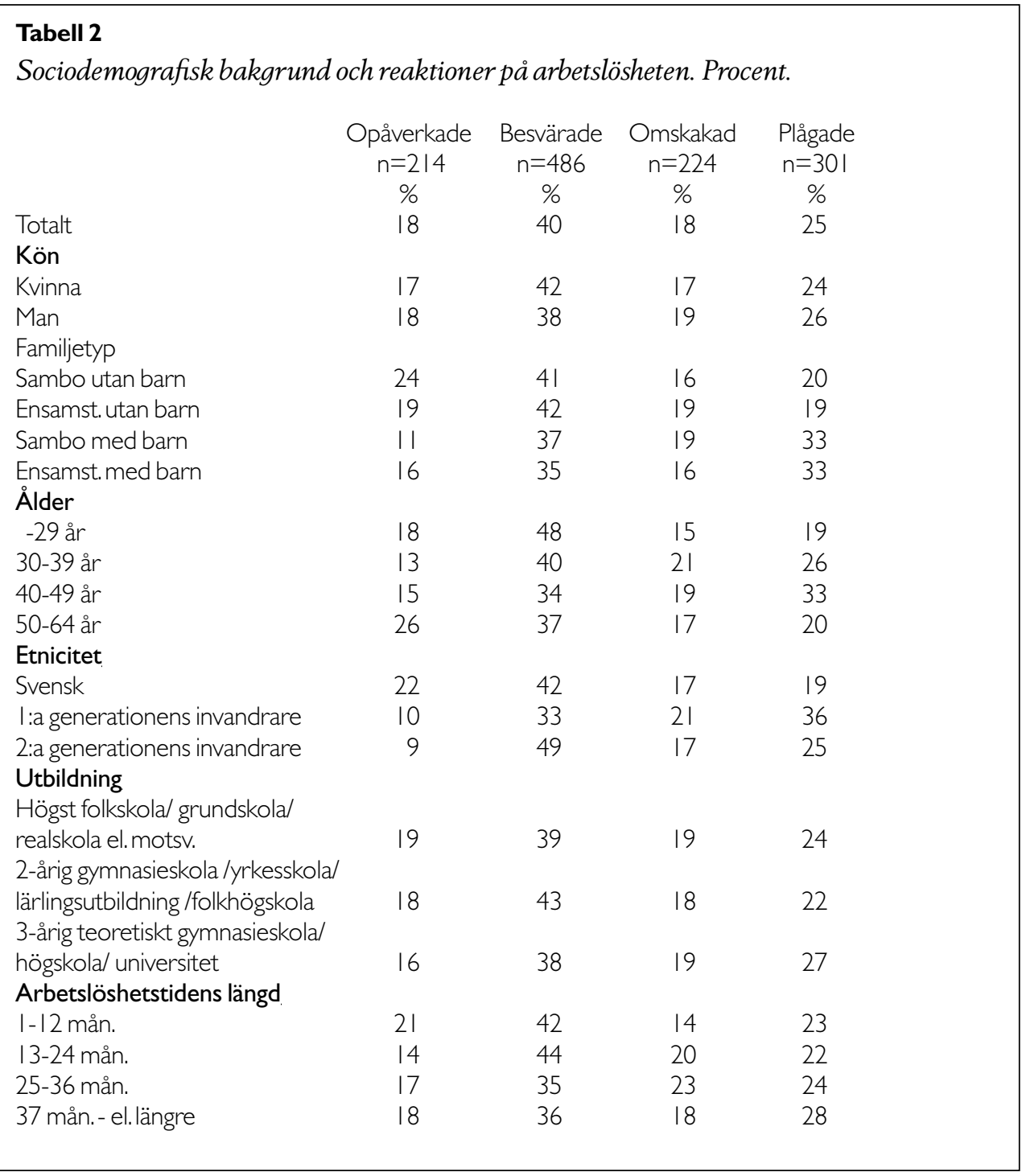

grad av ekonomisk påfrestning desto större andel som är Opåverkade av den. Detta gäller både för kvinnor och män. Bland kvinnor som är utsatta för »högre grad av ekonomisk påfrestning« är det 9 procent som är Opåverkade av arbetslösheten och 48 procent som är Plågade av den. Motsvarande siffror för män är 7 respektive 37 procent. Och bland kvinnor som är utsatta för »lägre grad av ekonomisk påfrestning« är det 28 procent som är Opåverkade av arbetslösheten och 11 procent som är Plågade av den. Motsvarande siffror för män är 39 procent respektive 13 procent.

I tabell 4 redovisas grad av skamgörande erfarenheter i relation till upplevelser av arbetslöshet bland kvinnor och män.

Av tabell 4 framgår att ju »mer skamgö-

Jönsson, L.R. \& Starrin, B. : Ekonomi-skam modellen... 


\section{Tabell 3}

Grad av ekonomisk påfrestning och reaktioner på arbetslöshet. Procent.

\begin{tabular}{|c|c|c|c|c|c|c|c|c|}
\hline \multirow[b]{2}{*}{$\begin{array}{l}\text { Ekonomisk } \\
\text { påfrestning }\end{array}$} & \multicolumn{2}{|c|}{ Opåverkade } & \multicolumn{2}{|c|}{ Besvärade } & \multicolumn{2}{|c|}{ Omskakade } & \multicolumn{2}{|c|}{ Plågade } \\
\hline & $\begin{array}{c}\text { kvinnor } \\
n=98\end{array}$ & $\begin{array}{c}\text { män } \\
n=104\end{array}$ & $\begin{array}{l}\text { kvinnor } \\
n=223\end{array}$ & $\begin{array}{c}\text { män } \\
n=224\end{array}$ & $\begin{array}{c}\text { kvinnor } \\
n=102\end{array}$ & $\begin{array}{l}\text { män } \\
n=|I|\end{array}$ & $\begin{array}{c}\text { kvinnor } \\
n=137\end{array}$ & $\begin{array}{l}\text { män } \\
n=150\end{array}$ \\
\hline Högre & 9 & 7 & 27 & 32 & 17 & 24 & 48 & 37 \\
\hline Medel & 12 & 10 & 50 & 47 & 18 & 20 & 20 & 24 \\
\hline Lägre & 28 & 39 & 43 & 37 & 18 & 12 & | | & 13 \\
\hline
\end{tabular}

\section{Tabell 4}

Grad av skamgörande erfarenheter och reaktioner på arbetslöshet. Procent.

Skamgörande
erfarenheter
Mer
Medel
Mindre

\begin{tabular}{cc}
\multicolumn{3}{c}{ Opåverkade } \\
kvinnor & män \\
$\mathrm{n}=98$ & $\mathrm{n}=104$ \\
4 & 4 \\
12 & 18 \\
34 & 36
\end{tabular}

\begin{tabular}{cc}
\multicolumn{2}{c}{ Besvärade } \\
kvinnor & män \\
$\mathrm{n}=223$ & $\mathrm{n}=224$ \\
31 & 30 \\
54 & 44 \\
38 & 40
\end{tabular}

\begin{tabular}{cccc}
$\begin{array}{c}\text { Omskakade } \\
\text { kvinnor }\end{array}$ & \multicolumn{2}{c}{ män } & \multicolumn{2}{c}{ kvåade } \\
kvinnor & män \\
$\mathrm{n}=102$ & $\mathrm{n}=1 \mathrm{II}$ & $\mathrm{n}=137$ & $\mathrm{n}=150$ \\
20 & 22 & 46 & 44 \\
18 & 23 & 16 & 15 \\
15 & 11 & 13 & 13
\end{tabular}

rande erfarenheter " desto större andel Plågade och ju "mindre skamgörande erfarenheterı desto större andel Opåverkade. Sambandet gäller både för kvinnor och män. Bland dem som har "mer av skamgörande erfarenheter« är det 4 procent av kvinnorna och 4 procent av männen som är Opåverkade av arbetslösheten. Motsvarande siffror för dem som har "mindre erfarenheter av att ha blivit skamgjordau är 34 respektive 36 procent. Av dem som har "mer av skamgörande erfarenheter" är det 46 procent av kvinnorna och 44 procent av männen som är Plågade av arbetslösheten. Motsvarande siffror bland dem som har mindre av sådana erfarenheter är för kvinnor och män 13 procent.

\section{Ekonomi-skam modellen och reaktioner på arbetslöshet}

I figur 3 och 4 kombineras faktorerna nekonomisk påfrestning"och »skamgörande erfarenheter" i ekonomi-skam modellen.

I figur 3 redovisas upplevelser av arbetslöshet i relation till "grad av ekonomisk påfrestning" och "grad av skamgörande erfarenheter« för kvinnor. I figur 4 redovisas motsvarade för män. I figurerna har endast kombinationerna "Högre-Mer», Högre-Mindre», „Lägre-Mer« och »Lägre-Mindre« medtagits. Kombinationerna med "Medel" redovisas i tabellerna 5 och 6 .

Av figur 3 och 4 framgår att den högsta andelen Opåverkade finns i gruppen "lägremindre«. I den är det 45 procent av kvinnorna (figur 3) och 53 procent av männen (figur 4) som Opåverkade av arbetslösheten. Den minsta andelen Opåverkade finns i kombinationen »högre-mer" (3 respektive 


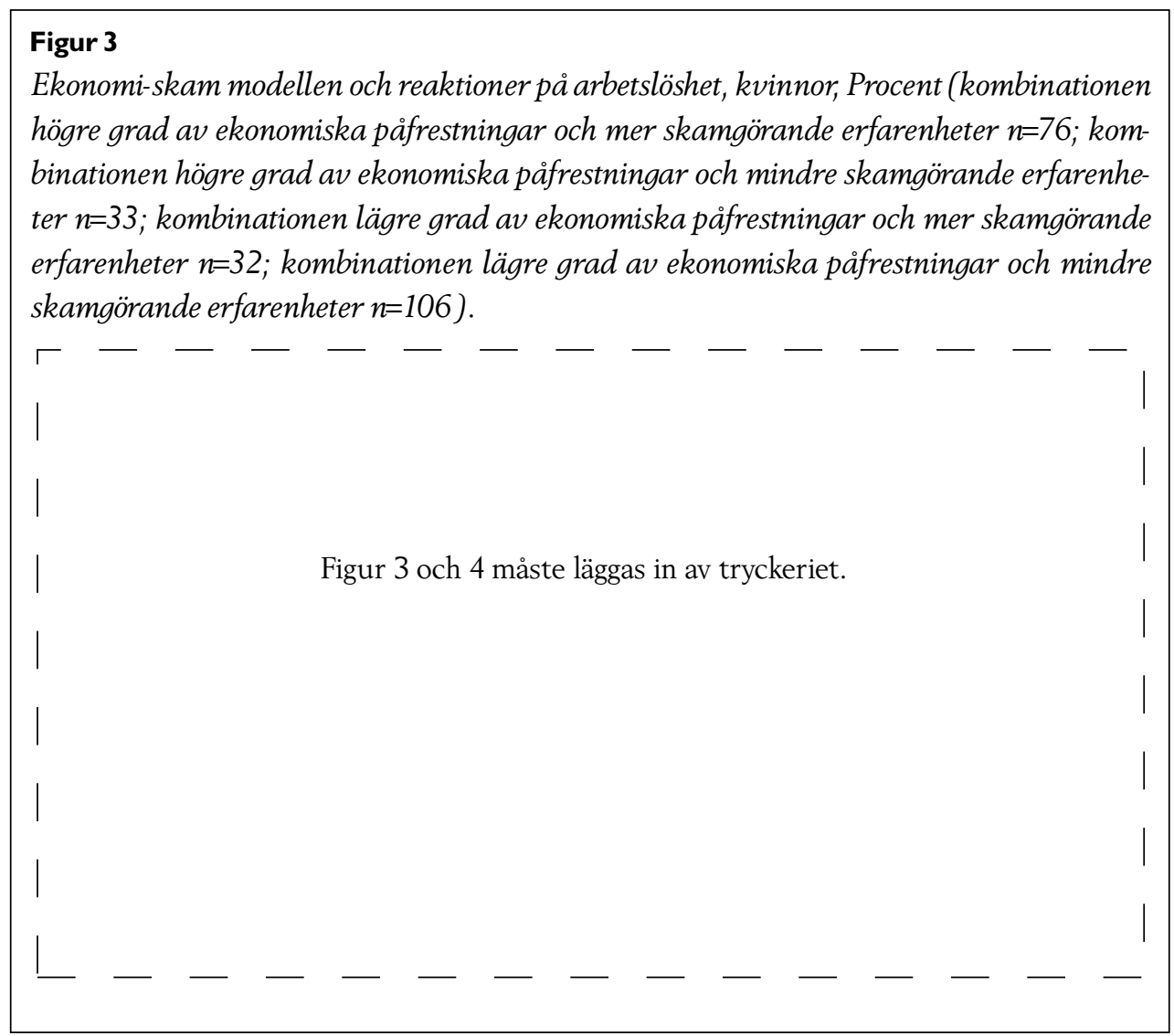

5 procent). Av figur 3 och 4 framgår också att den största andelen Plågade återfinns i gruppen "högre-mer». Andelen för kvinnor är 58 procent och för män 51 procent medan motsvarande siffror för kombinationen lägre-mindre är 5 respektive 9 procent. I tabell 5 redovisas resultatet av en multipel logistisk regressionsanalys avseende Opåverkade av arbetslöshet. ${ }^{2}$ Även här har en justering gjorts för faktorerna ålder, arbetslöshetstidens längd, familjetyp, utbildning ochetnisk bakgrund. Gruppen „Högre-Mer»

2 Den beroende variabeln reaktioner på arbetslöshet har dikotimiserats i „Ej Opåverkade» (omfattande grupperna » ßBesvärade", "Omskakade« och »Plågade») och »Opåverkade». är referensgrupp och värdet för den gruppen är satt till 1.0. Som framgår av tabell 5 är oddskvoten för att kvinnor skall vara Opåverkade av arbetslöshet ca 42 gånger större i gruppen "Lägre-Mindre" jämfört med referensgruppen „Högre-Mer«. Motsvarande siffra för män är 15. Vissa könsmässiga skillnader kan noteras. För män gäller att det är endast kombinationerna "Lägre-Medel" och "Lägre-Mindre» som är signifikanta. Förutsättningen för en signifikant ökning av oddskvoten är således lägre grad av ekonomisk påfrestning och då i kombination med "medel" eller "lägre" grad av skamgörande erfarenheter.

Förkvinnorgäller att en signifikant ökning

Jönsson, L.R. \& Starrin, B. : Ekonomi-skam modellen... 


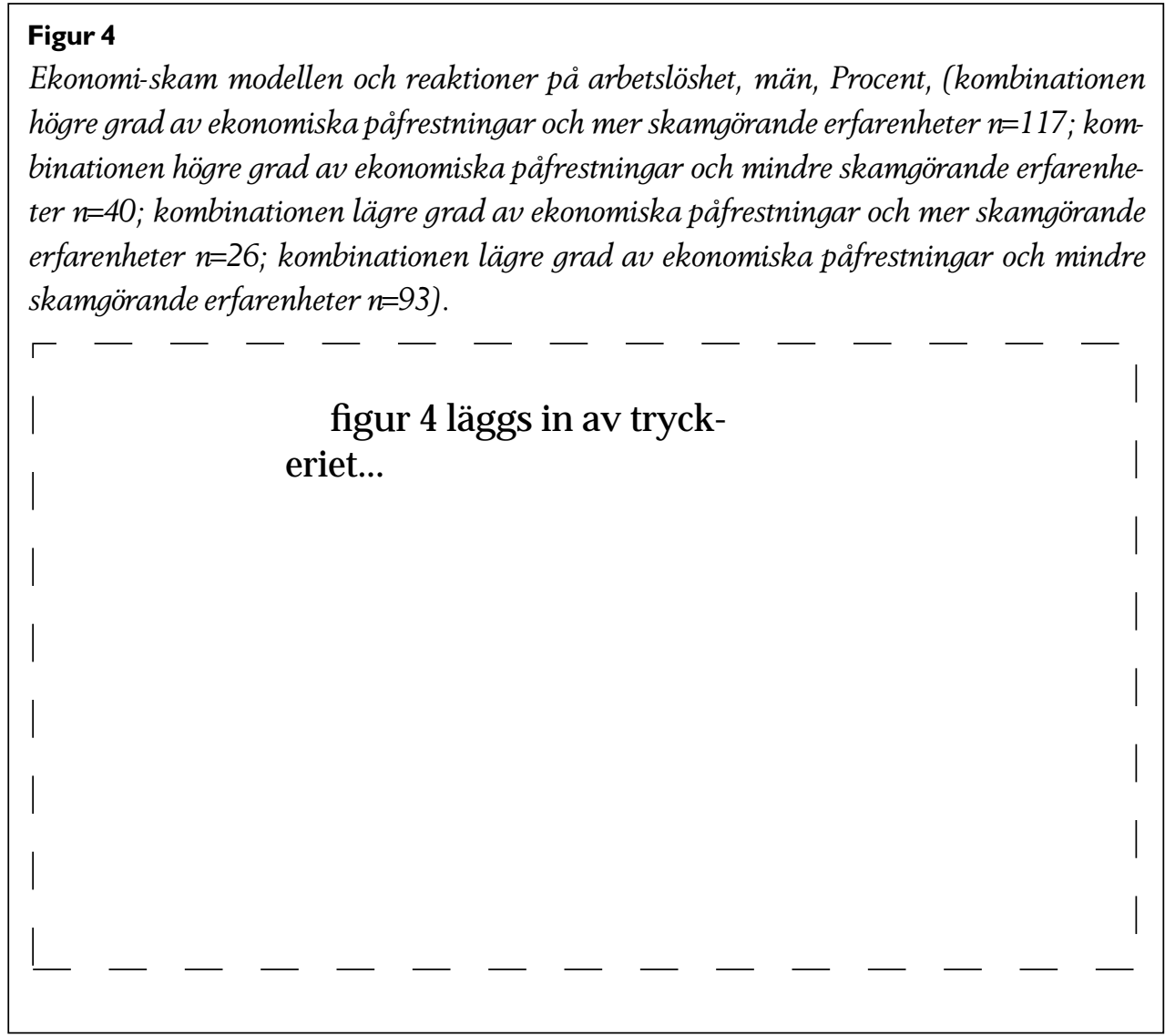

av möjligheterna att förbli Opåverkade av arbetslöshet föreligger även när den ekonomiska påfrestningen är på »högre» eller "medel« nivå under förutsättning då att de skamgörande erfarenheterna i det första fallet (högre grad av ekonomisk påfrestning) är "mindre» och i det andra fallet (medel grad av ekonomisk påfrestning) är »medel» eller "mindre».

Det förefaller således som att en betydande minskning av den skamgörande faktorn kan öka möjligheterna för kvinnor att förbli Opåverkade oavsett graden av ekonomisk påfrestning. För män gäller att en betydande minskning av den skamgörande faktorn endast kan åstadkomma en ökning av möjligheterna att förbli Opåverkade då den ekonomiska påfrestningen är lägre.

I tabell 6 redovisas resultatet av en multipel logistisk regressionsanalys avseende Plågade av arbetslöshet. ${ }^{3}$ Justering har gjorts för faktorerna ålder, arbetslöshetstidens längd, familjetyp, utbildning och etnisk bakgrund. Referensgrupp är »Lägre-Mindre» och referensvärdet är satt till 1.0. För kvinnor gäller att oddskvoten för att arbetslösheten skall bli plågsam är 37 gånger större i gruppen

3 Den beroende variabeln reaktioner på arbetslöshet har dikotimiserats $i$ „Ej Plågade» (omfattande grupperna "Opåverkade», "Besvärade», "Omskakade») och »Plågade». 


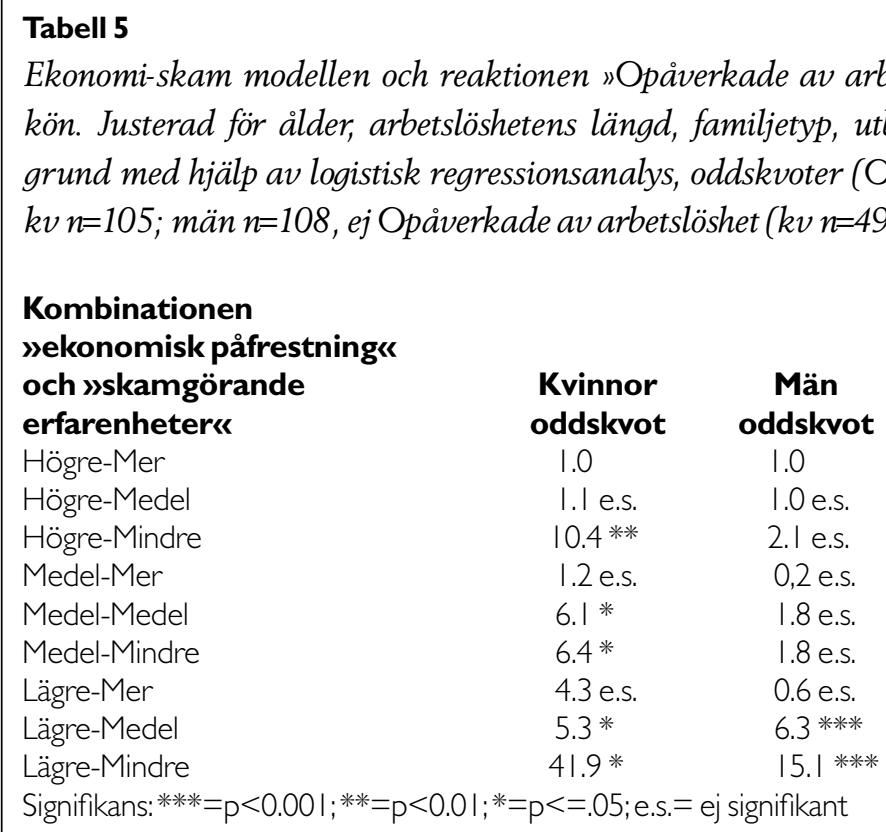

Ekonomi-skam modellen och reaktionen "Opåverkade av arbetslöshet«. Stratifierad för kön. Justerad för ålder, arbetslöshetens längd, familjetyp, utbildning samt etnisk bakgrund med hjälp av logistisk regressionsanalys, oddskvoter (Opåverkade av arbetslöshet $k v n=105$; män $n=108$, ej Opåverkade av arbetslöshet ( $k v n=497$; män $n=453$ ).

\section{Tabell 6}

Ekonomi-skam modellen och reaktionen "Plågade av arbetslöshet«. Stratifierad för kön. Justerad för ålder, arbetslöshetens längd, familjetyp, utbildning samt etnisk bakgrund med hjälp av logistisk regressionsanalys, oddskvoter (Plägade av arbetslöshet $k v n=143$; män $n=156$, ej Plågade av arbetslöshet ( $k v$ n=459; män n=455).

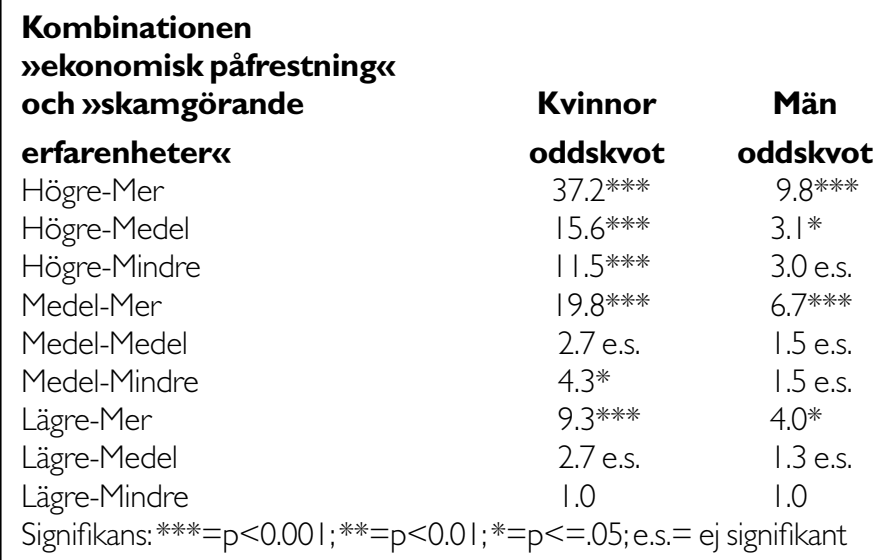

Jönsson, L.R. \& Starrin, B. : Ekonomi-skam modellen... 
„Högre-Mer« än i referensgruppen (LägreMindre). För män är oddskvoten ca 10 gånger större i gruppen "Högre-Mer« än i referensgruppen (Lägre-Mindre). Tendensen är att oddskvoterna för att arbetslösheten skall bli plågsam stiger med ökande grad av ekonomisk påfrestning och ökande grad av skamgörande erfarenheter. Denna tendens är tydligare för kvinnor än för män. För kvinnor gäller att oavsett graden av skamgörande erfarenheter föreligger en ökad risk att arbetslösheten blir plågsam när den ekonomiska påfrestningen är "högre». För män föreligger inte en ökning av denna risk för kombinationen »Högre-Mindre».

\section{Sammanfattning och diskussion}

\section{Sammanfattning}

Syftet med föreliggande undersökning var att studera sambandet mellan ekonomiska och sociala förhållanden - uttryckt $i$ ekonomi-skam modellen - och reaktioner på arbetslöshet uttryckt som fyra typbeskrivningar (Opåverkade, Besvärade, Omskakade och Plågade). Beskrivningarna är utformade som vinjetter. Det empiriska underlaget baserades på data från en enkätundersökning som riktades till arbetslösa i Skåne och som omfattande 1.249 personer $\mathrm{i}$ arbetsmarknadspolitiska åtgärder.

De Opåverkade utgjorde 18 procent av undersökningsgruppen, de Besvärade 40 procent, de Omskakade 18 procent och de Plågade 25 procent. Vinjettbeskrivningen för Opåverkad var "Arbetslösheten har inte påverkat mig alls. Jag känner mig tillfreds med min tillvaro just nu. Jag har hittills gått opåverkad ur situationen. Jag oroar mig inte för vad som kommer att hända i framtiden. Jag tror att saker och ting kommer att ordna sigu. Den lägsta andelen Opåverkade fanns i åldersgruppen 30-39år och största andelen i gruppen 50-64 år.

Vinjettbeskrivningen för Plågad var "Att vara arbetslös har varit plågsamt. Jag har känt mig mycket orolig, förtvivlad och nedstämd av att vara utan arbete. Tankar på vad som skall hända i framtiden gnager inom mig - tänk om jag inte lyckas få något nytt jobb. Jag känner mig mycket otillfredsställd med min tillvaro just nu.» Åldersmässigt skilde sig Plågade från de Opåverkade. Den lägsta andelen Plågade fanns i åldersgruppen 29 år eller yngre och störst andel i gruppen 40-49 år. Ca en tiondel av de Opåverkade och ca en tredjedel av de Plågade var första generationens invandrare. Bland svenskarna var motsvarande andel ca en femtedel.

Resultaten ger också ett visst stöd för hypotesen ju "lägre grad av ekonomisk påfrestning" och ju "mindre av skamgörande erfarenheter" desto större andel som upplever sig vara opåverkade av arbetslösheten. Men mönstret är långt ifrån entydigt. Det finns vissa komplicerade könsmässiga skillnader. Det förefaller som om en betydande minskning av den skamgörande faktorn kan öka möjligheterna för kvinnor att förbli Opåverkade oavsett graden av ekonomisk påfrestning. För män gäller att en sådan minskning av den skamgörande faktorn endast kan åstadkomma en ökning av möjligheterna att förbli Opåverkade om den ekonomiska påfrestningen är »lägre».

Resultaten från föreliggande undersökning ger stöd för hypotesen ju whögre grad av 
ekonomisk påfrestning» och ju "mer skamgörande erfarenheter" desto större andel som upplever sig vara plågade av arbetslösheten. Tendensen är att oddskvoterna för att arbetslösheten skall bli plågsam stiger med ökande grad av ekonomisk påfrestning och ökande grad av skamgörande erfarenheter. Vissa intressanta könsmässiga skillnader framträder. I sin helhet förefaller Ekonomiskam modellen ha en starkare koppling till reaktionen Plågade för kvinnor än för män. För kvinnor gäller att oavsett graden av skamgörande erfarenheter föreligger en ökning av risken att arbetslösheten blir plågsam när den ekonomiska påfrestningen är "högre«. För män inträder inte riskökningen för kombinationen "Högre-Mindre». Man kan också uttrycka det som så att för män gäller att mindre grad av skamgörande erfarenheter förefaller vara tillräckligt för att undvika att arbetslösheten blir plågsam.

Vi vill peka på några förhållanden som begränsar möjligheterna att dra mer långtgående slutsatser från föreliggande studie. För det första begränsar tvärsnittsstudier, som det här är fråga om, möjligheterna att dra slutsatser om kausala förhållanden. För detta krävs dels studier av longitudinell karaktär och dels detaljerade studier av kvalitativ art. För det andra är de beskrivningar av reaktioner på arbetslöshet som vi formulerat förenklingar av en verklighet som är betydligt mer komplicerad och svårfångad än vad som kan rymmas i typbeskrivningarna.

Som tagits upp har ekonomi-skam modellen i denna studie en starkare koppling till såväl reaktionstypen Plågade som Opåverkade för kvinnor än för män. Huruvida dessa skillnader är verkliga eller har att göra med metodmässiga frågor relaterade till undersökningens uppläggning och genomförande får framtida forskning utvisa.

\section{Avslutande diskussion}

Resultaten från föreliggande studie kan tolkas som att arbetslöshetens negativa sidor blir allt mer framträdande när den enskilde är utsatt för både en ekonomisk deprivation och en relationell deprivation. Kombinationen av den ekonomiska och den sociala deprivationen blir således till en stark ökning av den belastning som arbetslöshet per se kan innebära. Man skulle i detta sammanhang kunna tolka detta som att individen utsätts för olika slags belastningar. En typ av belastning som är primär och en annan som är sekundär. Den primära belastningen skulle då utgöras av arbetslösheten $i$ sig eller om man så vill förlusten av arbete. Medan de sekundära belastningarna skulle utgöras av att ytterliggare svårigheter tillstöter och som lägger sten på börda.

Den ena av de sekundära belastningarna handlar om allvarliga ekonomiska påfrestningar som yttrar sig i t.ex. att man tvingas pantsätta ägodelar, får svårigheter att betala räkningar i tid, tvingas att sälja ägodelar, avsaknad av ekonomisk buffert. Den ekonomiska påfrestningen kan i de mest allvarliga fallen utgöra ett allvarligt hot mot möjligheterna att försörja sig. Frågor som "Vad skall jag leva av?«»Hur skall jag klara av uppehället?» blir i det läget alltmer påträngande.

Den andra av de sekundära belastningarna handlar om upprepade skamgöranden som t.ex. tillvitelse av att vara lat, vara utsatt för andras irritation och ignorans. Skamgörandet utgör då ett påtagligt hot mot indi-

Jönsson, L.R. \& Starrin, B. : Ekonomi-skam modellen... 
videns själv, hennes sociala identitet och hennes sociala vara, vilket i de mest allvarliga fallen kan leda till socialt undandragande och t.o.m. social isolering.

Allvarliga ekonomiska påfrestningar utgör ett hot vars mest påtagliga emotionella reaktion föreslås vara rädsla (se Starrin, Forsberg \& Rantakeisu, 1999; Starrin \& Jönsson, 1998). Men även skamkänslan torde aktualiseras på grund av att ekonomin dessutom har en social dimension. Den handlar om frågan om att kunna leva upp till sociala förväntningar om ekonomiskt oberoende, av att kunna klara sig själv - något som värderas högt i samhället.

Erfarenheter av nedvärderande tillvitelser kan skapa skamkänslor som kan ta sig olika uttryck t.ex. känsla av mindervärde, känslan av att vara värdelös, minskat självförtroende, socialt tillbakadraganden. Skamkänslan är en indikation på otrygga och osäkra sociala band.

Sammanfattningsvis tolkar vi undersökningens resultat så att svåra ekonomiska påfrestningar och omfattande erfarenheter avskamgöranden under arbetslösheten utgör ett allvarligt hot mot individens vara - i fysisk, psykisk och social mening. De sekundära belastningarna, som utgörs av dels pålagringar av allvarlig ekonomisk slag och dels pålagringar av socialt nedvärderande slag, föreslår vi vara de faktorer som gör arbetslösheten till en plågsam upplevelse.

\section{Referenser}

Angelöw, B (1985) »Att leva under arbetslöshetshot» i Starrin, B., Lundberg, B. \& Angelöw, B red,; Tillsammans blir vi starka. Stockholm: Prisma.

Beales, H. \& Lambert, R S (1934) Memories of the Unemployed. London: Victor Golancz.

Berg, J.O (1997) "Den dolda världen - demografi och typologi« i Berg, J.O.(red.) Andersson, M., Björnug-Andersson, M., Bohman, S., Bäckström, C., Garsten, C., Maccoby, M., : Förnyare, Frustrerade och Fria agenter. Södertälje: City University Press.

Berkman, L. F. \& Syme, L.S (1979) "Social networks, host resistance and mortality: A nineyear follow-up study of Alameda County residents.» Am. J. Epidemiology, 109:2, 186-204.

Eales, M.J (1989) "Shame among unemployded men."Social Sience and Medicin, 28:8, 783-789.

Eisenberg, P \& Lazarsfeld, P (1938) „The psychological Effects on Unemployment.» Psychological Bullentin, 35, 358-390.

Gallie, D (1994) »Are the Unemployed an Under- class? Some Evidence from the Social Change and Economic Life Initiative."Sociology, 28:2, 737-757.

Giorgo, G. \& Unge, C (1998) „Ekonomisk stress, värdering av arbete och ohälsa." Socialmedicinsk tidskrift, 75:6, 291-296.

Hagquist, C. \& Starrin, B (1996) »Youth Unemployment and Mental Health - Gender Differences and Economic Stress."Scandinavian Journal of Social Welfare, 5:4, 215-228.

Hayes, J \& Nutman, P (1981) Understanding the Unemployed. London: Tavistock.

Horowitz, A (1984) »The Economy and Social Pathology."Ann. Rev. Sociol., 10, 95-119.

Jahoda, M., Lazarsfeld, P., Zeisel, H (1974) Marienthal: The Sociography of an Unemployed Community. London: Tavistock.

Jahoda, M(1982) Employment and Unemployment. Cambridge: Cambridge University Press.

Kaufmann, G(1993) The Psychology of Shametheory and treatment of shame-based syndroms. London: Routledge \& Kegan Paul.

Mohr, G. \& Freese, M (1978) »Arbeitslosigkeit und 
Depression" i Wacker, A., red.,: Vom Schock zum Fatalismus? Frankfurt: Surkamp.

Rantakeisu, U., Starrin, B. \& Hagquist, C (1997) "Unemployment, Shame and Ill-health - An Exploratory Study." Scandinavian Journal of Social Welfare, 6, 13-23.

Rantakeisu, U, Starrin, B. \& Hagquist, C (1999) „Financial hardship and shame - a tentative model to understand the social and health effects of unemployment." British Journal of Social Work, 29, 877-901.

Scheff, T.J (1990) Microsociology. Discourse, Emo tion, and Social Structure. Chicago: The University of Chicago Press.

Starrin, B. \& Larsson, G (1987) "Coping with unemployment: A contribution to the understanding of womenis unemployment."Social Science and Medicine, 2, 221-228.

Starrin, B. \& Lundberg, B (1993) „Uppsagd från järnverket - En studie av ekonomisk stress och ohälsa."Socialmedicinsk tidskrift, 70:5, 221-228.

Starrin, B., Rantakeisu, U. \& Hagquist, C (1996). "Om arbetslöshetens ekonomi och skam." Socialvetenskaplig tidskrift, 1-2, 91-114.

Starrin, B., Rantakeisu, U \& Hagquist, C (1997). "In the wake of the recession - economic hardship, shame and social erosion." Scandinavian
Journal of Work and Environment, 23, 47-54.

Starrin, B., Jönsson, L.R., Forsberg, E. \& Rantakeisu, U (1998). „Varför blir arbetslösheten till en plåga för vissa men inte för andra? « Socialmedicinsk tidskrift, 75:6, 280-290.

Starrin, B. \& Jönsson L.R (1998). „Ekonomisk påsfrestning, skamgörande erfarenheter och ohälsa under arbetslöshet - En prövning av ekonomi-skam modellen.». Arbetsmarknad \& Arbetsliv, 4:2,91-107.

Starrin, B., Forsberg, E. \& Rantakeisu, U (1999). I arbetslöshetens spår - ekonomisk stress, skam och ohälsa i Härenstam, A., Lindbladh, E., Lundberg, U. \& Starrin, B., red,: I vanmaktens spår. Om sociala villkor, utsatthet och ohälsa. Umeå: Boréa Bokförlag.

Wadel, C(1973). Now, Whose Fault Is That! - The struggle for Self-Esteem in the face of Chronic Unemployment. Memorial University of Newfoundland. Institut of Social and Economic Research. University of Toronto Press.

Viinamäki,H., Koskela, K., Niskanen, L. \& Arnkill, R (1993). „Unemployment, Financial Stress and Menthal Well-being: A Factory Closure Study." Eur. J. Psychiat., 7:2, 95-102.

Zawadski, B \& Lazarsfeld, P (1935). »The Psychological Consequences of Unemployment." Journal of Social Psychology, 6, 224-251.

\section{Summary \\ The economy-shame model and reactions to unemployment}

The results of the present study are based on a questionnairesurvey of 1,249 unemployed women and men of various ages and of differing ethic background who were taking part in labour-market measures at the time of the survey. The aim of the study was to use the economy-shame model to try to understand and explain why people react differently to unemployment. For this purpose, four type descriptions were formula- ted: Unaffected, Affected, Shaken, and Tormented by unemployment.

It was found that 18 per cent of the subjects were Unaffected, 40 per cent were Affected, 18 per cent were Shaken, and 25 per cent were Tormented. The proportions of women and men were roughly the same in the four ideal types. The largest share of Unaffected people were in the 50-64 age group and among those cohabiting and with

Jönsson, L.R. \& Starrin, B. : Ekonomi-skam modellen... 
no children living at home, whereas the largest share of Tormented people were found among families with children, in the 40-49 age group and in the group of first-generation immigrants.

The economy-shame model showed an association between, on the one hand, economic strain and shame-inducing experiences and, on the other hand, reactions to unemployment. Among women who were subject to a "higher degree of economic strain" and who had undergone "more shameinducing experiences", 3 percent were Unaffected by unemployment while 58 per cent were Tormented by it. The corresponding figures for men were 5 and 51 per cent respectively. Among women subject to a "lower degree of economic strain" and who had undergone "fewer shame-inducing experiences", 45 per cent were Unaffected by unemployment while 5 per cent were Tormented by it. The corresponding figures for men were 53 and 9 per cent respectively.

To sum up, the results of the study indicate support for the economy-shame model, namely, the higher the degree of economic strain and the more shame-inducing experiences, the more people are Tormented by unemployment. 